\title{
Penerapan Learning Management System BelajarBareng.id di SMK Negeri 1 Leuwiliang pada Masa Pandemi Covid-19
}

\author{
Nina*, Siti Khopipah A, Eni Rahmalia, Adinda F. Ramadani, Alya K. Mirawan, Chairunnisa, Firda \\ Herdianti, Azizzah A. Ardilla, Ingeu L. Wulandari \\ STKIP Muhammadiyah Bogor, Indonesia \\ *Coresponding Author: bila38310@gmail.com
}

Article History:

Received 2021-11-19

Revised 2021-12-09

Accepted 2022-01-17

DOI:

10.31949/educatio.v8i1.1686

\begin{abstract}
This research was motivated by problems in online learning during the Covid-19 pandemic at SMKN 1 Leuniliang. To overcome this problem, the school uses the LearningBareng.id LMS. This research is a descriptive qualitative research. The subject of this research is LMS LearningBareng.id owned by $S M K N 1$ Leuniliang, the sample of the research is accounts belonging to operators, teachers and students. The data collection technique is the method of observation, interviews and documentation. Based on the results of the study, it was concluded that the formation and implementation of the Learning Management System (LMS) of LearningBareng.id was influenced by educational technology and buman resources, including: (1) professionalism, (2) functional, (3) competitive), and (4) participation and cooperation. Learning Management System (LMS) BelajarBareng.id has very complete features, namely: (1) teacher administration, (2) academic calendar, (3) providing more varied materials and assignments, (4) discussion forums, (5) tracking, and (6) assessment. Strengths and advantages include easy teacher giving assignments to students, chat forum features to facilitate the discussion process in working on assignments, participation features for student attendance, quiz. assessments appear directly on student LMS, learning becomes more interesting and saves cost and time. While the drawbacks are that the teacher cannot upload files with large resolutions in the form of videos, audio, or documents, requires a stable internet connection, lacks real time interaction between teachers and students, requires devices such as computers, laptops, or cellphones.
\end{abstract}

Keywords: learning management system; learnbareng.id; the covid-19 pandemic

\section{Abstrak}

Penelitian ini dilatarbelakangi permasalahan dalam pembelajaran daring pada masa pandemi Covid-19 di SMKN 1 Leuwiliang. Untuk mengatasi permasalahan ini, sekolah tersebut menggunakan LMS BelajarBareng.id. Penelitian ini berjenis penelitian kualitatif deskriptif. Subjek penelitian ini adalah LMS BelajarBareng.id milik SMKN 1 Leuwiliang, sample penelitiannya akun milik operator, guru dan siswa. Teknik pengumpulan datanya dengan metode observasi, wawancara dan dokumentasi. Berdasarkan hasil penelitian disimpulkan bahwa pembentukan dan implementasi Learning Management System (LMS) BelajarBareng.id dipengaruhi oleh teknologi pendidikan dan sumber daya manusia antara lain:(1) profesionalitas, (2) fungsional, (3) kompetitif), dan (4) partisipasi dan kerjasama. Learning Management System (LMS) BelajarBareng.id memiliki fitur-fitur yang sangat lengkap, yaitu: (1) administrasi guru, (2) kalender akademik, (3) memberikan materi dan tugas yang lebih variatif, (4) forum diskusi, (5) pelacakan, dan (6) penilaian. Kelebihan dan keunggulannya antara lain guru mudah dalam pemberian tugas kepada siswa, fitur forum chat untuk memudahkan proses diskusi dalam pengerjaan tugas, fitur participation untuk absensi siswa, penilaian kuis langsung tampil di LMS siswa, pembelajaran menjadi lebih menarik dan hemat biaya dan waktu. Sedangkan kekurangannya adalah guru tidak dapat menggunggah file dengan resolusi yang besar baik berupa video, audio, atau dokumen membutuhkan koneksi internet yang stabil, kurangnya interaksi secara real time antara guru dan siswa, membutuhkan perangkat seperti komputer, laptop, atau handphone.

Kata Kunci: learning management system; BelajarBareng.id; pandemi Covid-19 


\section{PENDAHULUAN}

Pendidikan merupakan sumber pembangunan sebuah negara, bila pendidikan sebuah negara rendah maka perkembangan ekonomi, kesehatan, sosial, budaya dan politiknya pun akan rendah. Pernyataan ini senada dengan pendapat Sulisworo (2016) dalam Alifiyanti et al (2018) mengatakan bahwa daya saing suatu negara terkait pendidikan di era global abad 21. Pendidikan sebagai bagian 12 pilar daya saing yaitu: (1) lembaga, (2) infrastruktur, (3) lingkungan ekonomi makro, (4) kesehatan dan pendidikan dasar, (5) pendidikan tinggi dan pelatihan, (6) efisiensi pasar barang, (7) pasar tenaga kerja, (8) pasar keuangan, (9) teknologi, (10) kemutahiran bisnis, (11) inovasi, (12) kreatifitas. Tujuan utama pendidikan dalam pembangunan adalah bagaimana pendidikan dapat menciptakan sumber daya manusia yang memiliki daya saing bangsa yakni mampu meningkatkan kualitas pendidikan, sehingga dapat memperbaiki sistem pendidikan secara keseluruahan.

Perkembangan teknologi kini semakin berkembang pesat. Teknologi tidak hanya berkembang pada satu bidang saja tetapi diseluruh bidang ilmu termasuk di bidang pendidikan. Teknologi pendidikan dalam menunjang pembelajaran mulai dari papan tulis sampai laptop dan LCD proyektor. Tapi tidak semua sekolah mampu menyesuaikan perkembangan teknologi akibat kurang meratanya kemampuan sumber daya manusia dan infrastruktur di tiap daerah. Melihat kecenderuangan siswa dalam pemanfaatan teknologi pendidikan yang tinggi maka penggiat pendidikan harus mampu memanfaatkan media pembelajaran berbasis teknologi seperti social network, learning management system dan content management system. Terutama seperti kondisi saat ini akibat pandemi Covid-19, seluruh kegiatan pembelajaran dilaksanakan secara daring.

Pendidikan sebagai darma penting untuk membentuk SDM unggul maka pembelajaran secara daring kian meningkat untuk memastikan keterjangkauan dalam mengakses pendidikan. Maka, pemerintah menetapkan kebijakan Pembelajaran di Rumah sebagai upaya memutus penyebaran Covid-19. Sesuai dengan Surat Edaran Mendikbud Nomor 4 Tahun 2020 tentang Pelaksanaan Pendidikan Dalam Masa Darurat Coronavirus Disease (Covid-19. Berdasarkan obeservasi banyak penelitian tentang pembelajaran daring pada masa pandemi Covid-19. Pembahasannya antara tentang keunggulan dan kelemahan pembelajaran daring dan problematikanya. Permasalaham yang umum ditemukan adalah belum ada kesiapan guru untuk adaptasi dari pembelajaran konvensional menjadi pembelajaran berbasis teknologi. Lalu, menurunnya motivasi belajar siswa pada masa pandemik karena siswa lebih banyak menghabiskan waktu di rumah menggunakan gadget untuk main game atau menonton televisi menurut Alifiyanti\&Alifah dkk (2018:156). Selain itu, karena faktor geografi, sosial, dan ekonomi. Pertama, adalah faktor geografis karena siswa yang tinggal di wilayah pegunungan sehingga sulit mendapatkan sinyal internet. Kedua, faktor sosial adalah rendahnya dukungan orang tua. Ketiga, faktor ekonomi adalah rendahnya daya beli kuota internet yang dimiliki sebagian besar peserta didik dan masih ada peserta didik yang belum memiliki android untuk melaksanakan proses pembelajaran daring. Menurut Nadhiroh \& Hendrik (2021) pembelajaran daring sebelumnya sudah diterapkan di beberapa institusi namun bukan sebagai metode pembelajaran utama tapi semakin meningkatmya penyebaran Covid-19 menjadikan pembelajaran daring menjadi fokus utama dalam kegiatan pebelajaran. Hal ini tentu sangat berat karena siswa dituntut untuk memahami materi dan penggiat pendidikan dituntut kreatif dalam penyampaian materi melalui media berbasis teknologi informasi.

Salah satu sekolah yang terkena dampak pembelajaran daring adalah SMK Negeri 1 Leuwiliang. SMKN 1 Leuwiliang adalah sekolah kejuruan berbasis pertanian dibawah naungan Yayasan Pendidikan Michael D. Ruslim. Yayasan Pendidikan Michael D. Ruslim (YPA-MDR) secara khusus dibentuk oleh PT Astra International Tbk untuk melaksanakan tanggung jawab sosial perusahaan kepada masyarakat di bidang pendidikan. SMK Negeri 1 Leuwiliang berlokasi di Pabangbon kecamatan Leuwiliang, kabupaten. Bogor, memiliki tiga jurusan yaitu: (1) Agribisnis Pengolahan Hasil Pertanian (APHP), (2) Multimedia (MM), (3) Pengawasan Mutu Hasil Pertanian (PMHP). Dalam rangka mendukung proses pembelajaran daring di masa pandemi Covid-19, Yayasan Pendidikan Astra Michael D. Ruslim yang bekerja sama dengan B-One Coorporation merancang sebuah aplikasi pembelajaran digital yaitu Learning Management System (LMS). 
Kerjasama ini untuk mengintegrasikan aspek teknologi, pendidikan dan sumber daya manusia untuk mengatasi permasalahan pembelajaran pada masa pandemi Covid-19 di SMKN 1 Leuwiliang.

Learning Management System (LMS) ialah program pendidikan yang berbasis e-learning dan dapat digunakan dalam administrasi, dokumentasi, pelacakan, pelaporan, dan penyampaian (Ariesta, 2012; Darmawan, 2015; Sriyani, 2021). E-learning sebagai sembarang pengajaran dan pembelajaran yang menggunakan rangkaian elektronik (LAN, WAN, atau internet) untuk menyampaikan isi pembelajaran, interaksi, atau bimbingan (Arianti \& Yogisa, 2012; Cucus et al, 2016; Elyas, 2018; Setiawardhani, 2013; Syafrin \& Muslimah, 2021; Wijaya et al, 2020). Dalam lingkungan pendidikan, sistem seperti ini dapat digunakan untuk memantau proses pembelajaran, dan menyimpan segala jenis tugas dan penilaian. Menurut Budiarso (2008) menjelaskan bahwa dampak penerapan LMS di sekolah yaitu: (1) peserta didik memiliki kesempatan belajar secara mandiri tanpa ada batasan ruang dan waktu, (2) sumber belajar belajar siswa tidak hanya guru tapi dari beberapa sumber yang lain, (3) siswa di LMS dapat mengulang materi yang belum dipahaminya pada pembelajaran konvensional secara berkala, (4) siswa akan lebih termotivasi belajar karena inovasi pembelajaran, (5) kejenuhan pada pembelajaran konvensional dapat diatasi pada kelas virtual, (6) kegiatan belajar siswa tidak dibatasi pada jumlah mata pelajaran. Pendapat ini senada dengan Munir (2008) yang mengatakan bahwa unsur yang dimasukkan ke dalam pengembangan LMS harus melibatkan perkembangan siswa, antara lain hubungan dengan kehidupan yang sebenarnya artinya pendenkatan indirect-tematik (menyenangkan, meneguhkan positif dan mencari keilmuan).

Saat ini banyak LMS yang berkembang dan beredar di pasaran seperti: Google classroom, Edmodo, Atutor, Dreestyle Learning, ILIAS, Efront, Elink, BelajarBareng.id, Sakai dan masih banyak lagi. Menurut Abdul Hamid (2015) Learning Management System (LMS) semuanya bersifat Open Sourse artinya kode sumber pengembangnya dapat dikembangkan lebih lanjut sesuai kebutuhan dari masing-masing lembaga yang menggunakannya. Saat ini SMKN 1 Leuwiliang menggunakan LMS BelajarBareng.id yang dikembangkan oleh perusahaan B-One Coorporation. LMS BelajarBareng.id merupakan salah satu anak perusahaan B-One Coorporation yang bergerak di bidang digital teknologi pendidikan. BelajarBareng.id dibuat dengan menu yang berupa ikon-ikon yang interakktif dan mudah untuk digunakan. Bentuk LMS ini sudah mencakup banyak fitur seperti pembuatan konten pembelajaran, 4 lever akun (admin, guru, manager, dan siswa), management jurusan dan kelas, materi pembelajaran (PDF, teks, video\&audio), pembuatan form ujian, peringkat, unduh arsip, berita, kuis online, statistik pengunaan, kalender pendidikan, penilaian, video teleconference, serta fitur-fitur tambahan yang digunakan untuk komunikasi antara guru dan siswa, fitur pembayaran.

Berdasarkan uraian latar belakang, penelitian ini bertujuan untuk mendeskripsikan Penerapan Learning Menagement System di SMK Negeri 1 Leuwiliang serta mengetahui (1) fitur-fitur dalam LMS, (2) efektifitas penggunaan LMS, dan (3) kelebihan dan kekurangan LMS BelajarBareng.id di SMKN 1 Leuwiliang.

\section{METODE PENELITIAN}

Penelitian ini berjenis dekskriptif kualitatif, yaitu penelitian yang menggunakan latar alamiah dengan maksud menafsirkan fenomena yang terjadi dan dilakukan dengan jalan melibatkan berbagai metode yang ada (Moleong, 2017). Subjek penelitian ini adalah aplikasi Learning Management System (LMS) di SMKN 1 leuwiliang. Sampel penelitian menggunakan purposive sampling yaitu Learning Management System (LMS) milik operator dan Learning Management System (LMS) milik dua guru. Teknik pengumpulan data yang dipilih adalah observasi, studi dokumentasi dan wawancara. Sumber data penelitian ini ada 2 yaitu data primer dan data sekunder. Data primer diperoleh dari website Learning Management System (LMS). Sedangkan data sekunder diperoleh dengan teknik wawancara kepada guru dan siswa. Teknik pengumpulan menurut Sugiyono (2017) merupakan langkah yang paling strategis dalam penelitian, karena tujuan utama dari penelitian adalah mendapatkan data. Tanpa mengetaui teknik pengumpulan data, maka peneliti tidak akan mendapatkan data yang memenuhi standar yang ditetapkan.

Menurut Bogdan dalam Sugiyono (2017:244) analisis data adalah proses mencari dan menyusun secara sistematis data yang diperoleh dari hasil wawancara, catatan lapangan, dan bahan-bahan lain, sehingga dapat mudah dipahami, dan temuannya dapat diinformasikan oleh orang lain. Pada penelitian ini peneliti

Open Access: https://ejournal.unma.ac.id/index.php/educatio 
menganalisis data menggunakan metode deskriptif kualitatif. Data yang diperoleh melalui observasi, wawancara, dan studi dokumentasi dideskripsikan secara menyeluruh.

Penentuan jumlah data dibatasi sesuai dengan kebijaksanaan peneliti seperti yang diutarakan oleh Lincoln dan Guba (1985) dalam Moleong pada dasarnya penentuan masalah bergantung para paradigma apakah yang dianut oleh seorang peneliti, yaitu apakah ia sebagai peneliti, evaluator, ataukah sebagai peneliti kebijakan. Langkah pertama peneliti melakukan observasi langsung ke SMKN 1 leuwiliang pada tanggal 9 s.d 14 Oktober 2021. Kedua, melakukan studi dokumentasi dengan men-screenshot laman website Learning Management System (LMS). Ketiga, melakukan wawancara terhadap kepala sekolah, guru, dan siswa untuk memperoleh informasi terkait pembelajaran daring di SMKN 1 Leuwiliang. Untuk mempermudah alur penelitian perhatikan bagan pada gambar 1.

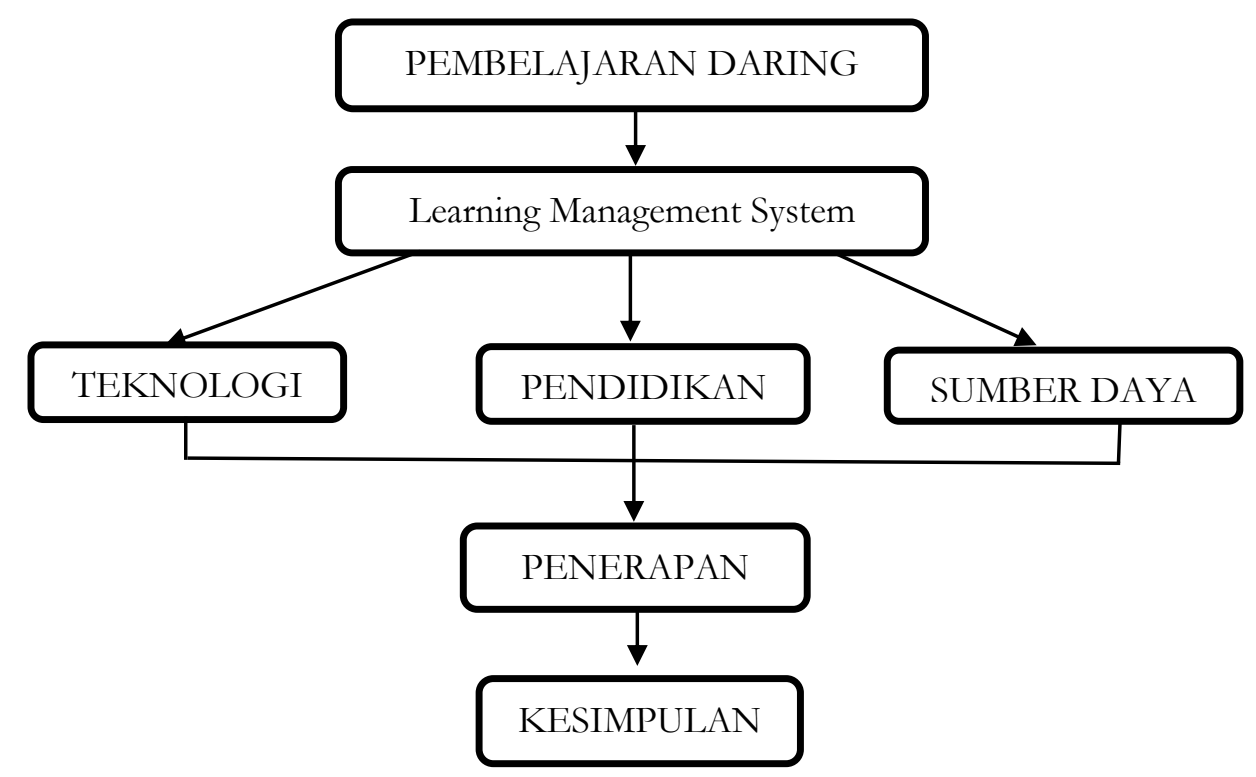

Gambar 1. Penerapan Learning Management System Di SMK Negeri 1 Leuwiliang

\section{HASIL DAN PEMBAHASAN}

Berdasarkan hasil analisis yang peneliti lakukan, terdapat dua poin penting dalam penerapan Learning Management System (LMS) di SMK Negeri 1 Leuwiliang yaitu: 1) Teknologi Pendidikan, 2) Sumber Daya Manusia.

\section{Teknologi Pendidikan}

Dalam Kamus Besar Bahasa Indonesia teknologi pendidikan merupakan metode bersistem untuk merencanakan, menggunakan, dan menilali seluruh kegiatan pengajaran dan pembelajaran dengan memperhatikan, baik sumber teknis maupun manusia dan interaksi antara keduanya, sehingga mendapatkan bentuk pendidikan yang lebih efektif. Di era digital 4.0 yang serba modern ini, proses pembelajaran harus selalu mengikuti perkembangan teknologi untuk menunjang proses pembelajaran demi tercapainya tujuan pendidikan. Implementasi teknologi pendidikan dalam proses pembelajaran salah satunya adalah penggunaan media pembelajaran. Di SMK Negeri 1 Leuwiliang media pembelajaran yang digunakan adalah Learning Management System (LMS). Pada saat ini pendidikan mengarah ke Student Centered Learning, sekolah harus menyediakan sumber yang relatif mudah diakses. Tidak hanya sumber tapi juga tempat dan waktu yang berbeda.

Penerapan Learning Management System (LMS) di SMK Negeri 1 Leuwiliang tentunya sangat berdampak baik pada sistem pembelajaran daring. Hal ini tentunya memberikan potensi yang besar dalam pemanfaatan teknologi di dunia pendidikan. Learning Management System (LMS) mempunyai fitur-fitur yang sangat lengkap. 
Melalui Learning Management System (LMS) ini guru lebih mudah membuat konten pembelajaraan daring mulai dari perencanaan, pelaporan, hingga dokumentasi. Selain itu, guru juga dapat memanfaatkan konten-konten dalam bentuk digital. Berdasarkan hasil penelitian yang dilakukan terhadap website Learning Management System (LMS) guru SMK Negeri 1 Leuwiliang terdapat berbagai fitur, perhatikan gambar 1.

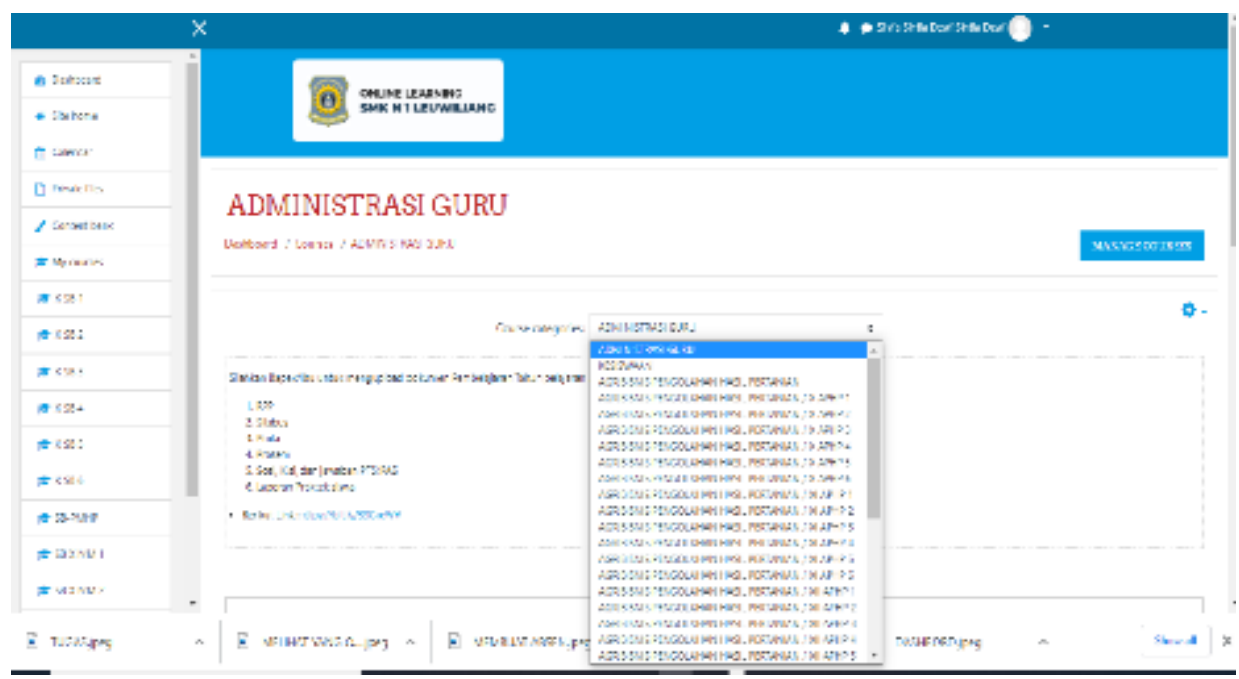

Gambar.1 Administrasi Guru

Pada fitur ini guru dapat mengunggah perangkat pembelajaran seperti RPP, silabus, program tahuan, program semester, soal, kisi-kisi jawaban dan laporan praktek sebagai perencanaan untuk menunjang proses pembelajaran.

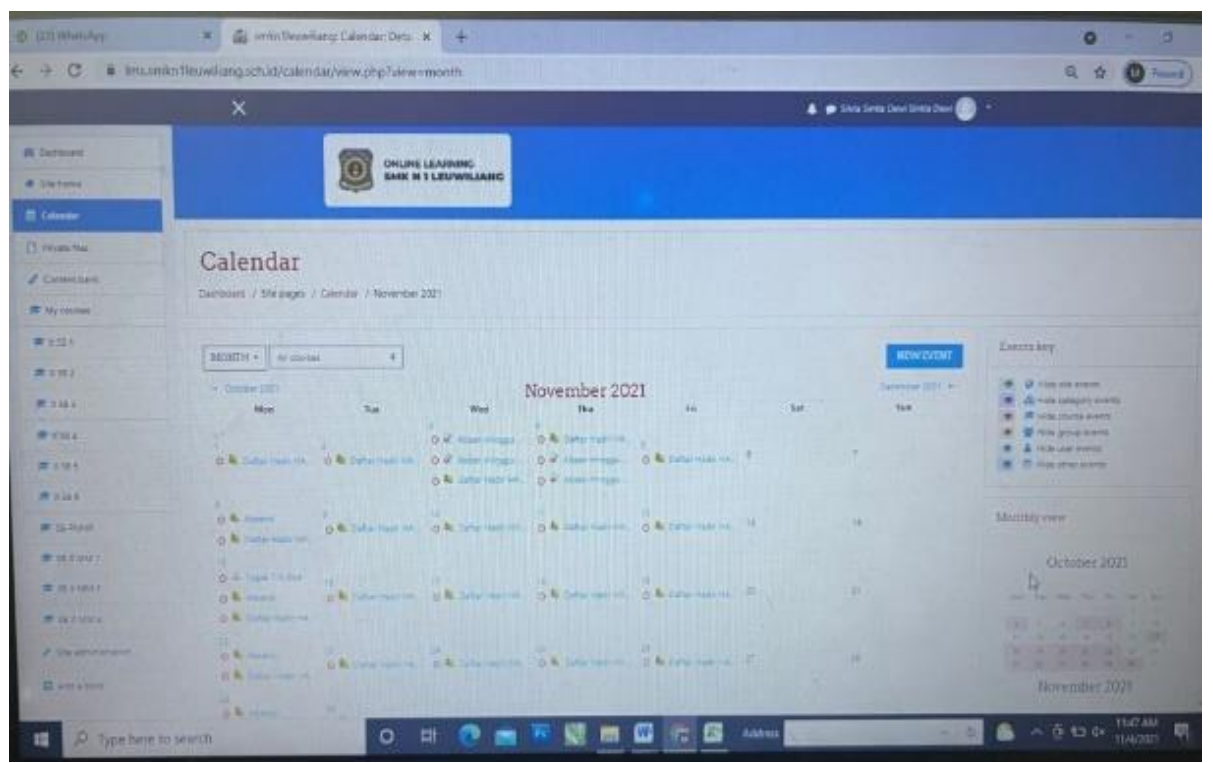

Gambar 2. Kalender Akademik

Dalam fitur ini menjelaskan kalender akademik dalam kegiatan pembelajaran yang akan dilaksanakan satu tahun ke depan, sesuai dengan aturan yang sudah ditentukan oleh Kementrian Pendidikan dan Kebudayaan dan disesuaikan kondisi sekolah. 


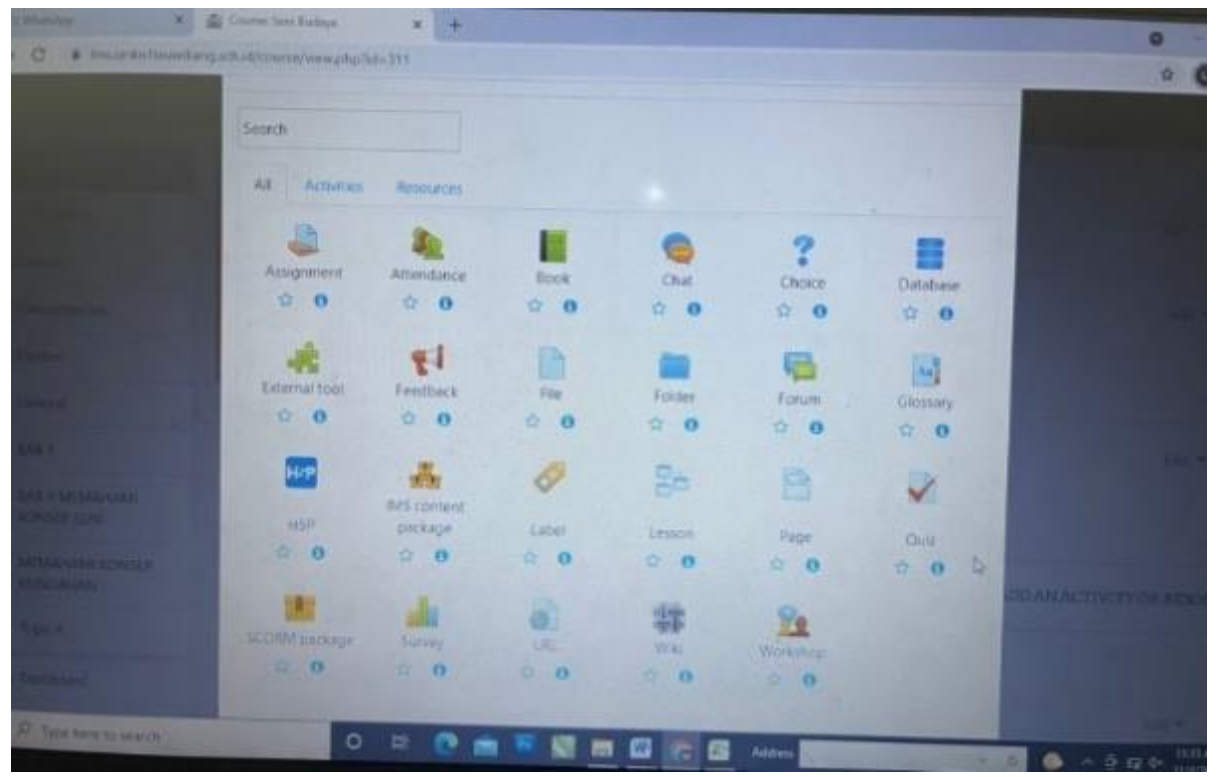

Gambar. 3 Fitur Materi dan Tugas dalam Pembelajaran

Pada fitur ini, guru memberikan materi pembelajaran dengan berbagai format misalnya PDF, PPT, word document, images, audio dan video. Bahkan guru bisa menyertakan tautan (link) untuk dipelajari siswa. Selain itu, dalam pengumpulan tugas guru mengharuskan siswa mengunggah konten digital. Misalnya esai, tugas proyek, kuis, laporan, dan lain-lain. Selanjutnya guru dapat melihat dan menilai tugas yang telah dikirim oleh siswa. Dengan begitu maka Learning Management System (LMS) telah memudahkan guru dalam pemberian materi atau bahan ajar dan memudahkan siswa dalam pengumpulan tugas.

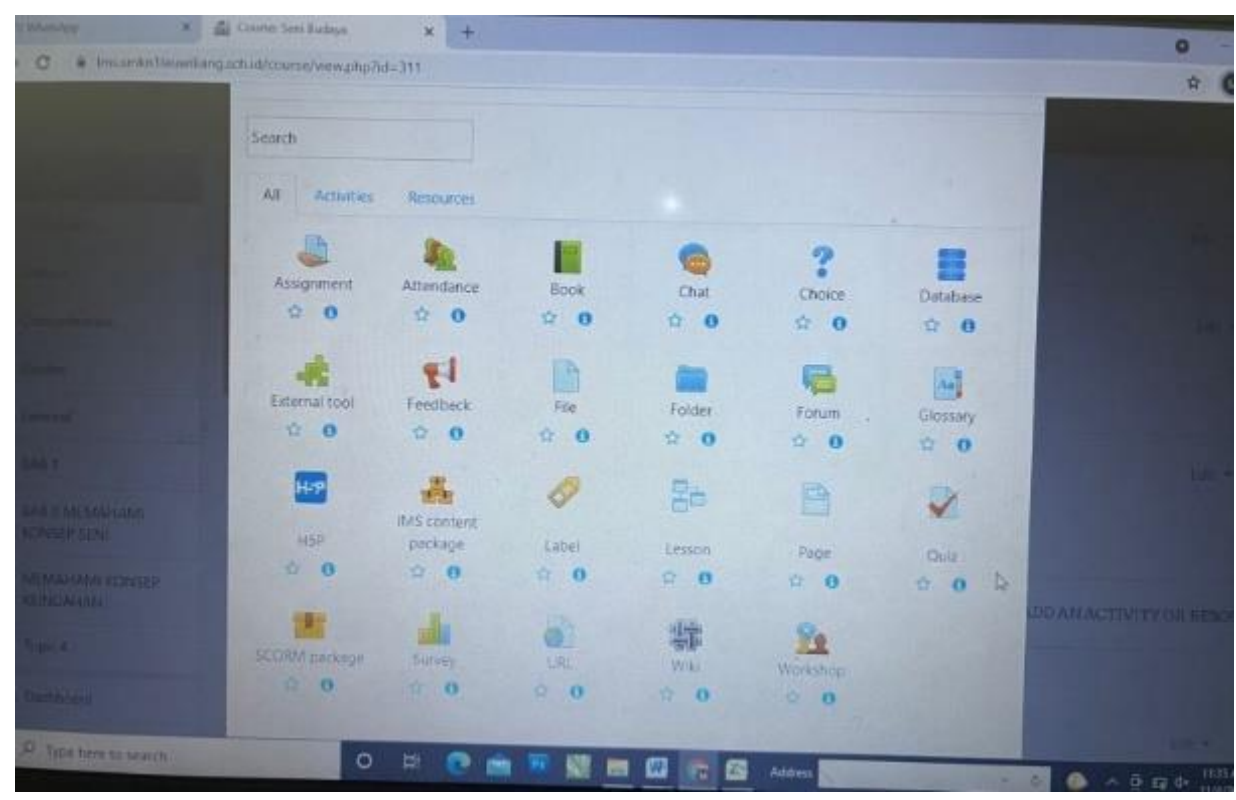

Gambar 4. Forum Diskusi

Selain pemberian materi atau pengumpulan tugas, antara guru dan siswa atau siswa dan siswa juga dapat berinteraksi melalui forum diskusi. Contoh interaksi antara guru dan siswa misalnya guru bisa memberikan komentar terhadap tugas yang sudah dikumpulkan oleh siswa. Adapun interaksi yang dapat dilakukan di antara para siswa yaitu saling bertugas pikiran mengenai materi pembelajaran pada grup chat masing-masing kelas. 


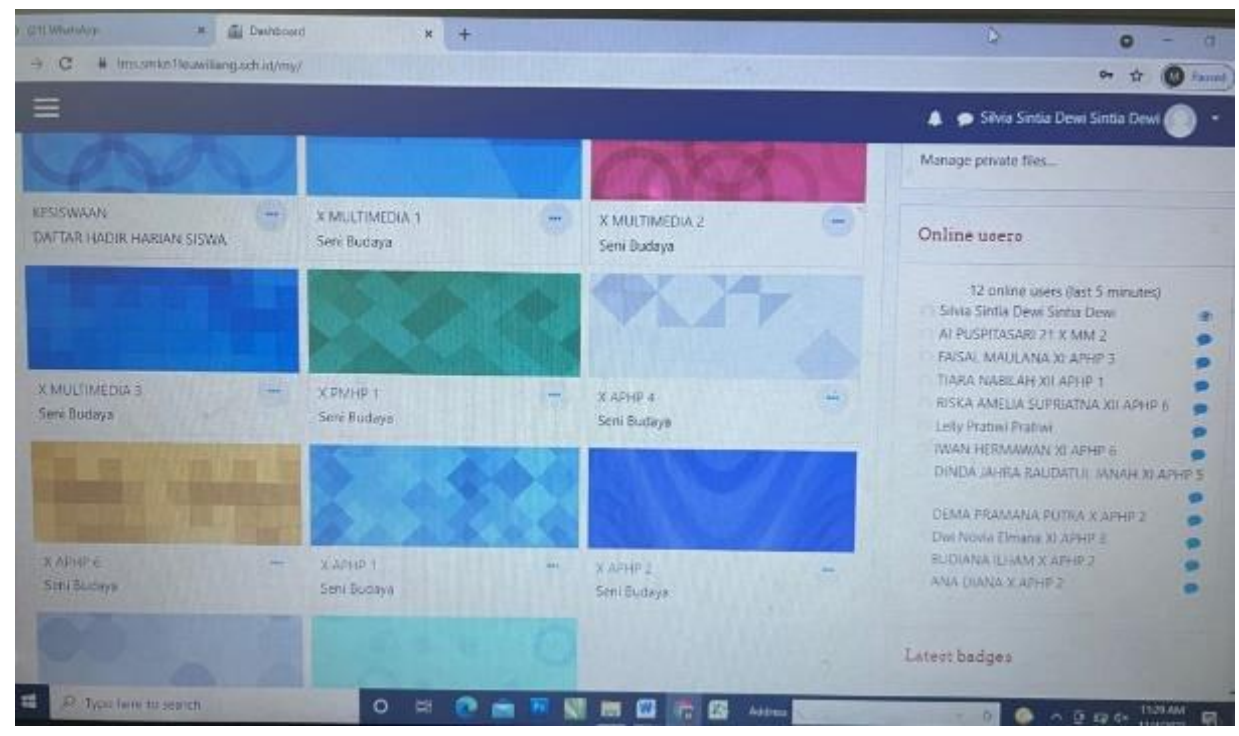

Gambar. 5 Pelacakan

Dalam fitur ini guru dapat mengetahui siswa yang aktif dan tidak aktif dalam menggunakan LMS. Guru akan melakukan evaluasi terhadap keaktifan siswa, bila ada siswa yang tidak aktif akan telusuri alas an dan penyebabnya agar proses pembelajaran bisa terlaksana dengan baik dan serentak.

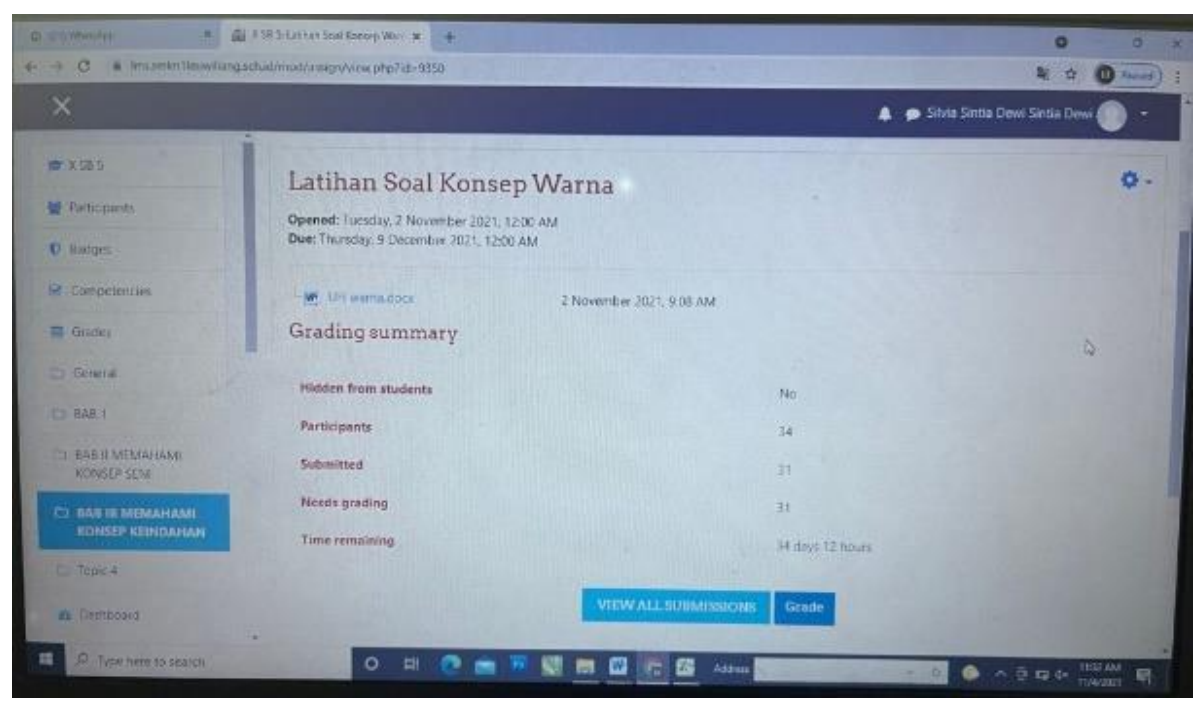

Gambar. 6 Penilaian

Sistem penilaian di Learning Management System (LMS) ini menjadi lebih mudah karena pada pembuatan soal latihan guru bisa menentukan skor pada tiap soal, jadi saat siswa men-submit soal latihan tersebut, maka nilainya akan langsung keluar. Tetapi hal tersebut hanya berlaku pada tipe soal pilihan ganda dan tipe soal mencocokkan, untuk tipe soal esai guru harus menghitung skornya secara manual.

Yayasan Pendidikan Astra Michael D. Ruslim bekerjasama dengan perusahaan teknologi B One Coorporation membuat LMS BelajarBareng.id untuk mengatasi permasalahan pembelajaran di SMKN 1 Leuwiliang. LMS ini dikendalikan oleh operator lalu dikelola oleh masing-masing dan siswapun berpartipasi menggunakan LMS dalam pembelajaran. Setiap bulan operator mengevaluasi setiap kegiatan pembelajaran dan tiap tiga bulan melakukan evaluasi dengan pihal B One Cooporation untuk meningkatkan kualitas dan kinerja LMS. Untuk mempermudah dalam memahami alur Learning Management System (LMS) di SMK Negeri 
1 Leuwiliang, maka peneliti membuat bagan alur pembentukan dan penggunaan Learning Management System (LMS), perhatikan gambar 8:

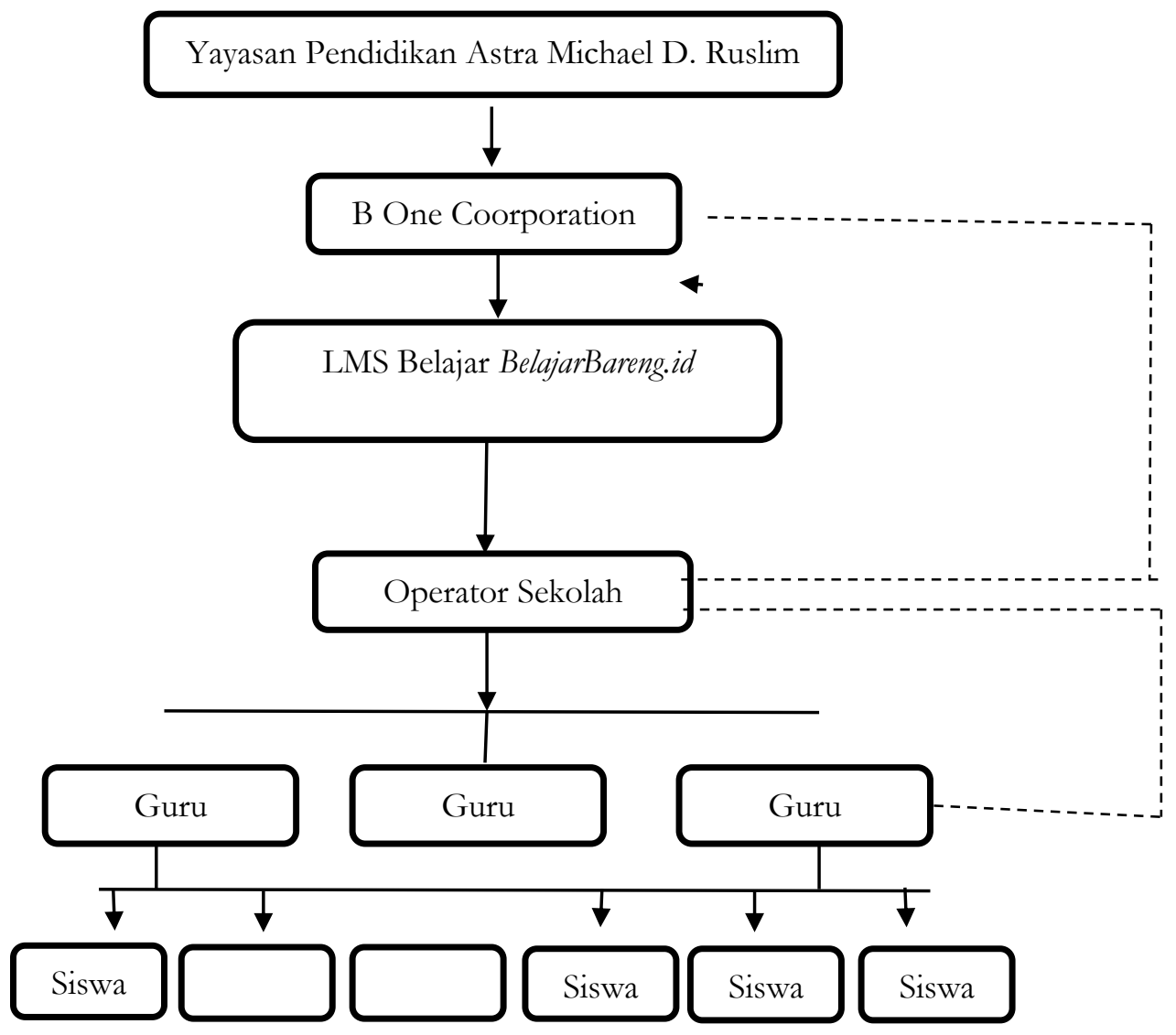

Gambar. 8 Bagan Pembentukan dan Penggunaan LMS BelajarBareng.id

Keterangan:

Garis putus sebagai jalur feedback

Garis hitam penghubung sebagai jalur koordinasi

\section{Sumber Daya Manusia}

Berdasarkan hasil observasi dan wawancara peneliti dapat menyimpulkan bahwa sumber daya manusia dalam pendidikan meliputi kepala sekolah, pendidik, staf tata usaha dan siswa. Tugas dari manajemen sumber daya manusia adalah mengelola potensi sumber daya manusia untuk mencapai tujuan pendidikan. Peneliti menemukan lima unsur dasar di SMK 1 Leuwliang antara lain: (1) profesionalitas, (2) kompetitif, (3) fungsional, (4) partisipasif, dan (5) kerjasama.

Profesionalitas adalah tingkatan kualitas atau kemampuan yang dimiliki sumber daya manusia dalam melaksanakan profesinya. Perlu digaris bahwa keprofesionalitasan tenaga pendidik adalah hal yang sangat penting karena mereka adalah garda terdepan dalam dunia pendidikan. Guru profesional hendaknya mengajar sesuai bidang kehliannya. Karena hal tersebut dapat mempermudah mentransfer pengetahuan kepeda peserta didik. Selain itu, guru profesional juga harus mengembangkan kapasitas yang dimiliki baik dalam segi pegetahuan, keterampilan, dan teknik mengajar. SMK Negeri 1 Leuwiliang memiliki standarisasi tenaga pendidik minimal S1 dan tenaga kependidikan minimal SMA/SMK/SLTA/Sederajat. Tenaga pendidik di SMK Negeri 1 Leuwiliang berjumlah 50 orang dan tenaga kependidikan berjumlah 18 orang. Seluruh karyawan di SMK Negeri 1 Leuwiliang sudah memenuhi standar profesional. Profesionalitas ini dapat ditingkatkan melalui Reskilling dan Upskilling yang bekerja sama dengan beberapa lembaga. Melalui pelatihan 
tersebut tenaga pendidik dan tenaga kependidikan mampu menyelaraskan kompetensi diri dengan kualitas sekolah.

Sumber daya manusia harus memiliki daya kompetitif yang tinggi, misalnya kreatif, ctitical thinking. Artinya sumber daya manusia yang kompetitif harus memiliki kecerdasan intelektual sehingga dapat menetukan strategi yang tepat. Pembentukan Learning Management System (LMS) menunjukan bahwa SMK Negeri 1 Leuwiliang memiliki tingkat kompetitif tinggi yang menjadikan SMK Negeri 1 Leuwiliang sebagai satu-satunya sekolah di Kecamatan Leuwiliang yang menggunakan Learning Management System (LMS). Selain itu, sumber daya manusia di SMK Negeri 1 Leuwiliang selalu melakukan pembaharuan pada Learning Management System (LMS) guna meningkatkan media pembelajaran yang optimal dan memiliki daya saing terhadap perkembangan teknologi pendidikan. Berdasarkan hasil observasi dan wawancara SMK Negeri 1 Leuwiliang adalah sekolah pertama di Kecamatan Leuwiliang yang menggunakan Learning Management System (LMS) BelajarBareng.id. Hal ini menjadikan SMK Negeri 1 Leuwiliang selangkah lebih maju dalam hal pembelajaran daring.

Fungsional mengacu pada sumber daya manusia yang mampu menunjukkan fungsinya untuk meningkatkan citra sekolah. Sumber daya manusia yang mampu adalah yang mempunyai motivasi intrinsik dan motivasi ekstrinsik. Motivasi instrinsik adalah motivasi yang berasal dari diri sendiri yamg berkaitan dengan etos kerja. Sedangkan motivasi ekstrinsik berkaitan dengan rekan kerja, lembaga, masyarakat, dan lingkungan yang mampu memberikan dorongan untuk mencapai tujuan pendidikan. Para pengajar SMKN 1 Leuwiliang memiliki motivasi yang tinggi untuk memahami prosedural LMS dengan cara mempelajarinya tutorial operasional LMS BelajarBareng.id di Youtube.

Sumber Daya Manusia yang memiliki keunggulan adalah sumber daya manusia yang mampu mengembangkan potensi diri untuk ikut berpastisipasi dalam kehidupan baik yang bersifat kompetitif, kooperatif, dan solidaritas sosial. Penting meningkatkan atau mengembangkan kecerdasan emosional, inteketual secara intergratif sehingga memiliki kekuatan yang sinergis dalam melaksanakan tugas. Pada pengimplementasiannya Learning Management System (LMS) di SMK Negeri 1 Leuwiliang meliputi operator, guru, dan siswa. Setelah dipersiapkan Learning Management System (LMS), selanjutnya Yayasan Pendidikan Astra Michael D. Ruslim melalui B One Coorporation melakukan sosialisasi dan pelatihan terhadap operator SMK Negeri 1 Leuwiliang untuk menguasai dan mengoperasikan Learning Management System (LMS) sesuai dengan fungsinya. Selanjutnya, operator mensosialisasikan kembali kepada guru dan siswa cara mengoperasikan Learning Management System (LMS) BelajarBareng.id. Hal tersebut membentuk kerjasama (team work) yang mampu menciptakan efisiensi dan efektivitas. Setelah menggunakan Learning Management System (LMS), SMK Negeri 1 Leuwiliang mengalami perubahan yang sangat significant baik dalam teknologi, sumber daya manusia, maupun sistem pembelajarannya.

\section{Kelebihan dan kekurangan penggunaan LMS}

Pada penerapan LMS BelajarBareng.id di SMKN 1 Leuwiliang, peneliti menemukan kelebihan dalam penggunaannya karena guru lebih mudah dalam pemberian tugas kepada siswa dan siswa lebih mudah dalam mengumpulkan tugas karena langsung menggunggahnya di LMS. Fitur di LMS terdapat forum chat untuk memudahkan proses diskusi dalam pengerjaan tugas. Fitur participation berfungsi untuk melihat keaktifan siswa dalam proses pembelajaran sebagai pengganti absensi. Penilaian akan langsung tampil di LMS masing-msing siswa setelah pemberian kuis. Pembelajaran menjadi lebih menarik karena materi yang diberikan lebih variatif dan inovatif. Terakhir kelebihan LMS ialah hemat biaya dan hemat waktu.

Sedangkan kekurangan dalam penggunaan LMS BelajarBareng.id, pertama guru tidak dapat mengupload file dengan resolusi yang besar baik berupa video, audio, ataupun dokumen (Word, PDF, Excel) untuk menunjang pembelajaran. Kedua, membutuhkan koneksi internet yang stabil selama pembelajaran. Ketiga, kurangnya interaksi secara real time antara guru dan siswa. Keempat, membutuhkan perangkat penunjang yang memadai, seperti komputer, laptop, atau handphone. 


\section{KESIMPULAN}

Berdasarkan pembahasan mengenai penerapan Learning Management System (LMS) BelajarBareng.id di SMK Negeri 1 Leuwiliang dapat disimpulkan sebagai berikut. Pertama pembentukan dan implementasi Learning Management System (LMS) sangat dipengaruhi oleh teknologi pendidikan dan sumber daya manusia yang unggul. Kedua, Learning Management System (LMS) memiliki fitur-fitur yang sangat lengkap, yaitu: 1) administrasi guru; 2) kalender akademik; 3) memberikan materi dan tugas yang lebih variatif; 4) forum diskusi; 5) pelacakan; 6) penilaian. Ketiga, bahwa dalam penerapan Learning Management System (LMS) di SMK Negeri 1 Leuwiliang tentu terdapat kelebihan dan kekurangan. Kelebihannya antara lain: guru lebih mudah dalam pemberian tugas kepada siswa dan siswa lebih mudah dalam mengumpulkan tugas karena langsung menggunggahnya di LMS, forum chat untuk memudahkan proses diskusi dalam pengerjaan tugas, fitur participation berfungsi untuk melihat keaktifan siswa dalam proses pembelajaran sebagai pengganti absensi, penilaian akan langsung tampil di LMS masing-masing siswa setelah pemberian kuis, pembelajaran menjadi lebih menarik dan hemat biaya dan hemat waktu. Sedangkan kekurangannya adalah guru tidak dapat mengupload file dengan resolusi yang besar baik berupa video, audio, ataupun dokumen (Word, PDF, Excel), membutuhkan koneksi internet yang stabil, kurangnya interaksi secara real time antara guru dan siswa, membutuhkan perangkat seperti komputer, laptop, atau handphone. Diharapkan hasil penelitian ini dapat menjadi bahan evaluasi untuk pemutakhiran dan pengembangan aplikasi LMS BelajarBareng.id untuk meningkatkan kualitas sistem pembelajaran di SMK Negeri 1 Leuwiliang.

\section{DAFTAR PUSTAKA}

Alifiyanti, I. F., Afifah, F. H., \& Ramadoan, N. (2019). Pemanfaatan learning management system (lms) berbasis edmodo materi fluida dinamis untuk peningkatan minat dan prestasi belajar fisika siswa sekolah menengah. In Prosiding SNFA (Seminar Nasional Fisika Dan Aplikasinya) (Vol. 3, pp. 155-162).

Ariesta, A. (2012). Kajian Learning Management System (LMS) dengan Qualitative Weight and SUM (QWS): Studi Kasus D3 Unggulan Universitas Budi Luhur. Budi Lubur Information Technology, 9(2).

Arianti, Y. M., \& Yogisa, K. (2012). Aplikasi e-Learning Berbasis Web dengan Menggunakan Atutor. UG Journal, 6(1).

Budiarso, D. E. A. (2008). Pengembangan E-Learning Berbasis Moodle (Modular Object Oriented Dynamic Learning Environment) Sebagai Alternatif Model Pembelajaran dan Penunjang Perkuliahan di Jurusan Kurikulum dan Teknologi Pendidikan Unnes. Skripsi. Semarang: Program Sarjana Unnes.

Cucus, A., Aprilinda, Y., \& Endra, R. Y. (2016). Pengembangan e-learning berbasis multimedia untuk efektivitas pembelajaran jarak jauh. Explore: Jurnal Sistem Informasi dan Telematika (Telekomunikasi, Multimedia dan Informatika), 7(2).

Darmawan, A. (2015). Pemilihan Sistem Learning Management System (LMS) Metode AHP Menggunakan Criterium Decision Plus 3.0. Faktor Exacta, 7(3), 260-270.

Elyas, A. H. (2018). Penggunaan model pembelajaran e-learning dalam meningkatkan kualitas pembelajaran. Warta Dharmawangsa, (56).

Hamid, A. (2015). Efektivitas Implementasi LMS (Learning Management System) Efront terhadap Minat dan Hasil Belajar pada Mata Pelajaran Pemprograman WEB di SMKN 8 Semarang. Skripsi. Universitas Negeri Semarang.

Nadhiroh, D., \& Hendrik, H. (2021). Pembelajaran daring di masa pandemi: Literatur Review. Automata, 2(2).

Moleong, L J. (2017). Metodologi Penelitian Kualitatif. Bandung: PT. Remaja Rosdakarya.

Munir. (2008). Pembelajaran Jarak Jauh Berbasis Teknologi Informasi dan Komunikasi. Bandung: Alfabeta

Setiawardhani, R. T. (2013). Pembelajaran Elektronik (E-Learning) Dan Internet Dalam Rangka Mengoptimalkan Kreativitas Belajar Siswa. Edunomic Jumal Pendidikan Ekonomi, 1(2).

Sriyani, I. (2021). Google classroom sebagai solusi pembelajaran jarak jauh mata pelajaran administrasi 
umum. Indonesian Journal of Education and Learning, 4(2), 456-461.

Sugiyono. 2017. Metode Penelitian Kuantitatif, kualitatif dan R\&D. Bandung: Alfabeta.

Syafrin, S., \& Muslimah, M. (2021). Problematika Pembelajaran E-learning dimasa Pandemi Covid-19 bagi Santri Pondok Pesantren Al-Hasyimiyyah Kotawaringin Barat. Jurnal Al-Qiyam, 2(1), 10-15.

Wijaya, R., Lukman, M., \& Yadewani, D. (2020). Dampak Pandemi Covid19 Terhadap Pemanfaatan E Learning. Jurnal Dimensi, 9(2), 307-322. 